\title{
Contrasting Incentives for Earnings Management: Board Activity and Board Remuneration in Spanish Firms
}

\author{
Paolo Saona, Laura Muro, Ryan McWay, Mauricio Jara \\ Saint Louis University, Saint Louis University, University of San Francisco, Universidad de \\ Chile \\ paolo.saona@slu.edu, laura.muro@slu.edu, rmcway@dons.usfca.edu, \\ mjara@unegocios.cl
}

\begin{abstract}
We analyze the effect board activity and board remuneration has on earnings management (EM). Our results show that more active boards are inefficient in preventing earnings manipulation. Regarding board compensation we find a U-shaped relation indicating that excessive remuneration will lead to more earnings management. Policy recommendations are derived from the findings.
\end{abstract}

Index Terms-Earnings management, board remuneration, corporate governance.

\section{INTRODUCTION}

The OECD/G20 Principles on Corporate Governance establish that the governance framework should ensure the strategic guidance of the company, the effective monitoring of management, and the board's accountability to the company and the shareholders. ${ }^{1}$

Spain has developed a strong regulation in corporate governance. For instance, the Spanish Unified Good Governance Code of Listed Companies adopts modern trends in corporate governance, stated by different entities and institutions such as the OECD, the Basel Committee on Banking Supervision and the European Commission, and considers the comments and proposals put forward by economic operators and institutions. Jensen [1] identifies the role of board of directors as an internal governance mechanism that mitigates agency conflicts. Hence, although the primary activity of directors is to monitor managerial decisions to maximize shareholders' wealth; there is a wide concern over boards' inefficiency in achieving this objective [2]. For instance, these improvements to the legal framework have not been effective in preventing financial scandals as in the cases of Bankia, Afinsa and many others; highlighting the inability of board of directors to inhibit earnings manipulation.
One way in which managers divest resources, mislead outside investors, and consume private benefits is through the opportunistic manipulation of financial reporting [3], to which the board of directors has a role in constraining such practices [4]. This paper analyses two board features that condition EM activities: board activity and board compensation.

The hypothesis concerning board activity suggests that more active boards oversee the performance of executives in a timely manner more consistently, and efficiently, and consequently curbs the level of EM. Zgarni, Halioui and Zehri [5] suggest that the frequency of board meetings depends on its duties delegated to ensure that the performance of the board meets the intended objectives. Hence, boards that meet infrequently are characterized by poor monitoring as suggested by Xie, Davidson lii and DaDalt [6], who find that more active boards monitor more effectively corporate financial statements, preventing EM. Therefore, it is hypothesized that the frequency of board meetings is negatively correlated with EM.

Board compensation plans are designed with the intent to encourage directors to wisely advise managers, monitor their performance, and ultimately maximize their shareholders' wealth. Such compensation packages have been a priority in the agenda of governance reforms [7] since high compensation systems have compromised the directors' objectivity in performing governance [8]. Prior research provides significant insights on the relationship between executive compensation and how it molds EM [9, 10], but little is known about the relationship between board compensation and EM. To this respect, Ye [11] is the only notable exception who analyses independent director cash compensation on EM in China, suggesting a positive relationship between the two leading to increased EM.

1 G20/OECD Principles of Corporate Governance. http://www.oecd.org/daf/ca/principles-corporategovernance.htm 
Regarding board compensation, we identify two competing approaches that explain its impact on EM. The incentive hypothesis suggests that higher cash reward will provide directors with monetary incentives to monitor managers, which reduces EM [12]. Performance-based compensation will align directors' and shareholders' interests and will also provide information about the fact that more attention to shareholder value maximization reinforces the role of the board in preventing EM. A similar conclusion on the alignment approach is reached by Kim, Roden and Cox [13], who suggest that greater cash-based compensations are used to attract quality directors, as well as to establish a better agency relationship between directors and shareholders than equity-based compensation.

The alternative explanation supports the perverse incentive hypothesis, which posits that high compensation may encourage directors to reciprocate high cash compensation by reducing oversight of managers, triggering higher EM. This hypothesis suggests that when compensation schemes transfer excessive wealth to board members, directors see themselves motivated to become more indulgent towards management [14]. This hypothesis is characterized by a mutual back scratching situation associated with excessive compensation and weak monitoring known as cronyism [8]. Well-compensated directors may be less likely to exercise constructive criticism and allow managers to expand their discretion to self-interestedly manipulate financial reports. Excessive compensations may characterize an environment where managers and directors connive, sheltered in cronyism, to consume private benefits at the expense of shareholders that reduces the pressure of internal monitoring, engaging managers in more aggressive EM. Given that the incentive hypothesis is plausible to be expected at relatively low compensation levels, whilst the perverse incentive hypothesis is expected at excessive compensations, we hypothesize a pioneering $U$-shaped relationship between board compensation and EM.

\section{METHODOLOGY AND DATA}

Our sample comprises of 135 non-financial Spanish listed firms from the years 2008 to 2016. The financial statements were obtained from Thomson Reuters EIKON

2 This econometric technique arises as a superior approach in comparison to the difference GMM [15] Arellano M and Bond S 1991 Some tests of specification for panel data: Monte Carlo evidence and an application to employment equation The Review of Economic Studies 58 277-97 because the GMM-SE expands the instrument lists by including instruments in levels and instruments in differences, providing higher consistency in the estimator and better asymptotic precision [16] Brown P, Beekes $\mathrm{W}$ and Verhoeven $\mathrm{P}$ 2011 Corporate governance, accounting and finance: $A$ and the information concerning board features was manually collected from the Annual Report of Corporate Governance published by the Spanish Stock Exchange Commission. Our data combines time-series and crosssectional information, allowing the formation of panel data from which we estimate the regressions using the two-stage Generalized Method of Moments System Estimator (GMM-SE) with robust standard errors. ${ }^{2}$

Discretionary accruals are employed as proxy for EM. Like most accrual-based earnings manipulation measures, we proceed in the first stage by modeling the nondiscretionary accruals, and in the second stage estimating the discretionary (or abnormal) accruals as the residuals in the estimated model. Three alternative measures of discretionary accruals are used as robustness checks. The first one follows Dechow, Sloan and Sweeney [20] which is base on total accruals. The second model follows García and Gill-de-Albornoz [21] which employs the working capital accruals version of the Jones [22] model instead of the total accruals. The third model corresponds to the Jones [22]'s cash-flow modified model of Kasznik [23] which included the change in operating cash-flow in the model. Given that we are interested in the magnitude of the manipulation of financial statements and not in its direction, the absolute value of these three discretionary accruals $\left(\left|D A_{i t}\right|\right)$ measures are used as proxy of EM for $i$ firm in $t$ period.

The explanatory variables of EM are the board activity (BActiv ${ }_{i t}$ ), corresponding to number of board's annual meetings; board compensation measured as total compensation of the board of directors as a share of total assets $\left(B R e m 1_{i t}\right)$, and alternatively as the average compensation per director $\left(B R e m 2_{i t}\right)$ in million euros. Board remuneration variables enter the models with their squared transformations to test the non-monotonic relationship suggested in our second research hypothesis. Control variables include the board size $\left(B S i z e_{i t}\right)$ calculated as the number of directors that integrate the board of directors; the insider ownership concentration (InsOwn $n_{i t}$ ) measured as percentage of shares closely held (e.g. executives, directors, cross-holdings, majority shareholder, and those without necessarily senior positions but with significant decision making power); the firm size $\left(\right.$ Size $\left._{i t}\right)$ calculated as the logarithm of total assets; leverage ratio $\left(L e v_{i t}\right)$ corresponding to the addition of short- and long-term debt over total common equity; the profitability of assets $\left(R O A_{i t}\right)$ computed as

review Accounting \& Finance 51 96-172, [17] Alonso-Borrego C and Arellano M 1999 Symmetrically normalized instrumental variable estimation using panel data Journal of Business \& Economic Statistics 17 36-49, [18] Arellano M and Bover O 1995 Another look at the instrumental variable estimation of error-components models J. Econometrics 68 29-51, [19] Blundell R and Bond S 1998 Initial conditions and moment restrictions in dynamic panel data models J. Econometrics 87 115-43. 
net income over total assets, and the default risk ( $R i s k_{i t}$ ) based on Altman [24]'s Z-score. 3 Industry sector and temporal dummy variables were created to fit the models. The model takes the following form:

$$
\left|D A_{i t}\right|=\beta_{0}+\beta_{1} \text { BActiv }_{i t}+\beta_{2} \text { BRem }_{i t}+
$$

$\beta_{3}$ BRem $_{i t}^{2}+\beta_{4}$ BSize $_{i t}+\beta_{5}$ InsOwn $_{i t}+\beta_{6}$ Size $_{i t}+$

$\beta_{7}$ Lev $_{i t}+\beta_{8} R O A_{i t}+\beta_{9} Z_{i t}+\beta_{10}$ DummyInd +

$\beta_{11}$ DummyTemp $+\eta_{i}+\mu_{t}+\varepsilon_{i t}$

$\eta_{i}$ is the firm specific effect, $\mu_{t}$ is the time effect and $\varepsilon_{i t}$, the error term, and all other variables are defined above. The expected signs of $\beta_{2}$ and $\beta_{3}$ are not trivial. The condition $\beta_{2}<0<\beta_{3}$ must be fulfilled to test the hypothesized U-shaped relationship. For doing so, the Lind and Mehlum [25] contrast is used to test if the nonmonotonic relationship is statistically significant.

\section{EMPIRICAL RESULTS}

Table 1 displays summary statistics of variables. The fist test we apply corresponds to the assessment that the absolute values of the discretionary accruals are statistically different from zero. The zero-mean difference test indicates that the mean values of the three proxies of EM (|DA1|, $|D A 2|$, and $|D A 3|)$ are statistically different from zero, evidencing that listed Spanish firms discretionally manipulate their results, either by increasing earnings or by reducing them. The board of directors for a typical Spanish company usually met 9.76 times a year (BActiv), the total compensation of the board of directors amounted to $1.12 \%$ of the firm's total assets (BRem1), corresponding to 128.8 (thousand $€$ ) average per director (BRem 2 ). The closely held shares (InsOwn) averaged 63.46\%, evidencing how concentrated the ownership structure among majority shareholder, executives, directors and other relevant insiders is in the Spanish corporate sector. Table 1 shows also the correlations among variables.

Table 2 provides sound evidence of a positive and statically significant relationship between the board's annual meetings and the extent of EM. This means that managers of firms in which board meets more often are more prone to manipulate the financial reports. This finding rejects our first research hypothesis, suggesting that more active boards do not necessarily monitor managers better in the Spanish corporate sector. In fact, bureaucratic supervision of managerial decisions allows managers to engage in opportunistic overstatements of financial information. Another explanation might be that

3 Altman's Z-score is defined as Risk $=1.2 X 1_{i t}+$ $1.4 X 2_{i t}+3.3 X 3_{i t}+0.6 X 4_{i t}+0.99 X 5_{i t}$, where $X 1_{i t}$ is working capital/total assets; $X 2_{i t}$ is retained earnings/total assets; $X 3_{i t}$ is earnings before interest and tax/total assets; $X 4_{i t}$ is market value of equity/total liabilities; and $X 5_{i t}$ is sales/total assets.

${ }^{4}$ The critical points are calculated by optimizing each regression outputs relative to the $B R e m$ variables, and then equalizing the regression to zero. After that we must directors attend more meetings to get the retributions for meeting attendance, increasing their own wealth, and not necessarily in the benefit of the shareholders that they represent. This reflects a widespread agency problem in listed firms in our sample. Jensen [1] finds that in wellfunctioning organizations the board should be relatively inactive and an increase in the activity is a sign of the need for solving problems. Vafeas [26] finds that higher board activity is related to poor performance as evidence of agency problems.

The findings related to our second research hypothesis also support this agency argument. Table 2 shows that there is a non-monotonic, U-shaped relationship between the two alternative measures of board compensation schemes and the proxies of discretionary accruals. This $U$-shaped connection is fathomed out given that the condition $\beta_{2}<0<\beta_{3}$ is fulfilled. This U-shaped relationship indicates that when board compensation increases, directors efficiently monitor managers, constraining EM. However, such a controlling role becomes fatuous when compensations are excessively high. In such scenario, tacit alliances are created between directors and managers where each group advocate in expropriating wealth from shareholders, tunneling resources toward their private benefit. Such behavior induces cronyism, whereby mutual back scratching between directors and managers reduces the firm's governance quality, creating room for active EM. Our findings suggest that board compensation is subject to diminishing returns, and therefore can be optimized at $0.56 \%$ of the firm's total assets, following a U-shaped relationship.

The Lind and Mehlum [25] contrast tests whether the non-monotonic relationships are statistically significant in all regressions (e.g. see p-values of the displayed critical points). 4 The average critical point for $B R e m 1$ variable exhibited in Table 2 is $0.86 \%$ of total assets which is comparatively lower than the mean value of BRem 1 variable of $1.12 \%$ as exhibited in Table 1 . This means that a typical Spanish firm operates under the perverse incentive hypothesis fostering EM. The findings are alike concerning the BRem 2 variable, where the average critical point among the last three regressions in Table 2 (115.2 thousand $€$ ) is slightly lower than its mean value observed Table 1 (128.8 thousand $€$ ). Consequently, our findings emphasize the opportunistic conduct of board members in consenting to the overstatement of reported earnings for private benefits; where their role to oversee managers is relaxed when their compensation depends

solve for BRem that represents the point at which the discretional accruals are minimized. For instance, for regression (1) in Table 2 the first derivative takes the form $\partial A b s D A 1 / \begin{gathered}\partial B \operatorname{Rem} 1=-0.2931 \times \text { BRem }+2 \times \\ 26.2578 \times \text { BRem }\end{gathered}=0$. Hence, when BRem $1=0.56 \%$, EM are minimized and from that point onward the perverse incentive hypothesis dominates the incentive hypothesis. Similar calculation are applied in all the other regression in the table. 
on the accounting performance of the company. Hence, our second research hypothesis is accepted.

\section{CONCLUSIONS}

We observe indulgent boards in monitoring managers when the salary of board members is beyond optimization. Therefore, we suggest that boards' compensation packages should be reformulated to optimize board efficiency for Spanish firms with the purpose of reducing EM.

We also find that more active boards do not reduce the potential for managers to engage in EM. This finding, against our expectation, could be explained because of high bureaucracy levels within the board structure that could lead to inefficient decision-making processes and the need to meet more frequently. Board activity does not act as an efficient corporate governance mechanism. These results highlight the importance of board features on preventing EM as a mechanism of corporate governance.

Even though the Spanish regulation has improved considerably on this respect, there still is work to be done [27]. This change in the legal framework could result in a decrease in the capacity of managers to manipulate earnings. Our work could be extended to other European countries for a comparative analysis focused on different legal frameworks and the potential effects that they could have on EM. 
Table 1.

\begin{tabular}{|c|c|c|c|c|c|c|c|c|c|c|c|c|c|c|}
\hline & Variable & Mean & Std. Dev. & 1 & 2 & 3 & 4 & 5 & 6 & 7 & 8 & 9 & 10 & 11 \\
\hline 1 & |DA1| & $0.0389 * * *$ & 0.0226 & 1.0000 & & & & & & & & & & \\
\hline 2 & |DA2| & $0.0202 * * *$ & 0.0233 & 0.5759 & 1.0000 & & & & & & & & & \\
\hline 3 & |DA3| & $0.0540 * * *$ & 0.0745 & 0.2205 & 0.4969 & 1.0000 & & & & & & & & \\
\hline 4 & BActiv & 9.7559 & 3.7083 & 0.0186 & -0.0313 & 0.0208 & 1.0000 & & & & & & & \\
\hline 5 & BRem1 & 0.0112 & 0.0050 & 0.0621 & 0.2084 & 0.1772 & -0.1303 & 1.0000 & & & & & & \\
\hline 6 & BRem2 & 0.1288 & 0.1180 & -0.0375 & -0.1211 & -0.0293 & 0.2040 & -0.2164 & 1.0000 & & & & & \\
\hline 7 & InsOwn & 0.6346 & 0.2346 & -0.1178 & -0.0961 & -0.0372 & -0.1631 & -0.1170 & -0.0588 & 1.0000 & & & & \\
\hline 8 & BSize & 10.7116 & 3.9999 & -0.0626 & -0.2037 & -0.1931 & 0.1491 & -0.3711 & 0.2455 & -0.0747 & 1.0000 & & & \\
\hline 9 & Size & 20.9647 & 2.4706 & -0.1006 & -0.2695 & -0.1770 & 0.2358 & -0.3814 & 0.3360 & -0.0211 & 0.3395 & 1.0000 & & \\
\hline 10 & Lev & 1.9284 & 1.4224 & -0.0174 & -0.0904 & 0.0545 & 0.1672 & -0.2825 & 0.1250 & -0.0261 & 0.1814 & 0.3483 & 1.0000 & \\
\hline 11 & ROA & 0.0173 & 0.0180 & -0.1494 & -0.1104 & -0.0926 & -0.1348 & 0.0332 & 0.1549 & 0.0711 & 0.0922 & 0.1315 & -0.3126 & 1.0000 \\
\hline 12 & Risk & 2.3764 & 1.2229 & -0.0232 & 0.0788 & 0.0369 & -0.2618 & 0.2823 & -0.0155 & 0.0315 & -0.1915 & -0.1716 & -0.3850 & 0.2025 \\
\hline
\end{tabular}


Table2.

\begin{tabular}{|c|c|c|c|c|c|c|}
\hline VARIABLES & $\begin{array}{c}(15) \\
\text { absdam3 }\end{array}$ & $\begin{array}{c}(22) \\
\text { absdam4 }\end{array}$ & $\begin{array}{c}\text { (29) } \\
\text { absdam5 }\end{array}$ & $\begin{array}{c}(21) \\
\text { absdam3 }\end{array}$ & $\begin{array}{c}(28) \\
\text { absdam4 }\end{array}$ & $\begin{array}{c}\text { (35) } \\
\text { absdam5 }\end{array}$ \\
\hline BActiv & $\begin{array}{l}0.0005^{*} \\
(1.1383)\end{array}$ & $\begin{array}{l}0.0006^{*} \\
(1.4151)\end{array}$ & $\begin{array}{c}0.0043 * * \\
(2.2059)\end{array}$ & $\begin{array}{c}0.0003 * * * \\
(4.6339)\end{array}$ & $\begin{array}{c}0.0004 * * * \\
(8.3429)\end{array}$ & $\begin{array}{c}0.0027 * * * \\
(32.3996)\end{array}$ \\
\hline BRemun1 & $\begin{array}{c}-0.2931 * * \\
(-2.0592)\end{array}$ & $\begin{array}{c}-0.8536 * * \\
(-2.1444)\end{array}$ & $\begin{array}{c}-8.1379 * * * \\
(-19.4648)\end{array}$ & & & \\
\hline BRemun $1^{2}$ & $\begin{array}{c}26.2578 * * * \\
(7.9085)\end{array}$ & $\begin{array}{c}43.7949 * * * \\
(21.9036)\end{array}$ & $\begin{array}{c}389.7611^{* * *} \\
(29.2650)\end{array}$ & & & \\
\hline Critical Point & $0.0056^{* *}$ & $0.0097^{*}$ & $0.0104 * * *$ & & & \\
\hline BRemun2 & & & & $\begin{array}{l}-0.0066^{*} \\
(-1.6367)\end{array}$ & $\begin{array}{c}-0.0117 * * * \\
(-19.0369)\end{array}$ & $\begin{array}{c}-0.0430 * * \\
(-2.0282)\end{array}$ \\
\hline${\text { BRemun } 2^{2}}^{2}$ & & & & $\begin{array}{c}0.0281^{* * *} \\
(9.6362) \\
\end{array}$ & $\begin{array}{c}0.0508 * * * \\
(16.1103) \\
\end{array}$ & $\begin{array}{c}0.1901 * * * \\
(32.9526) \\
\end{array}$ \\
\hline Critical Point & & & & $0.1174 * * *$ & $0.1152 * * *$ & $0.1131 * * *$ \\
\hline BSize & $\begin{array}{c}-0.0009 * * * \\
(-9.5511)\end{array}$ & $\begin{array}{l}-0.0010^{*} \\
(-1.7823)\end{array}$ & $\begin{array}{c}-0.0023 * * * \\
(-6.3227)\end{array}$ & $\begin{array}{c}0.0003 \\
(0.3287)\end{array}$ & $\begin{array}{c}0.0004 \\
(0.6224)\end{array}$ & $\begin{array}{c}-0.0008^{* * *} \\
(-3.4337)\end{array}$ \\
\hline InsOwn & $\begin{array}{l}-0.0052 * \\
(-1.0016)\end{array}$ & $\begin{array}{c}-0.0118 * * * \\
(-15.3899)\end{array}$ & $\begin{array}{c}0.0399 \\
(0.4594)\end{array}$ & $\begin{array}{l}-0.0053 \\
(-0.4345)\end{array}$ & $\begin{array}{c}-0.0081 * * * \\
(-1.6256)\end{array}$ & $\begin{array}{c}0.0210 \\
(0.7079)\end{array}$ \\
\hline Size & $\begin{array}{c}0.0022^{* * *} \\
(9.2414)\end{array}$ & $\begin{array}{c}-0.0031 * * * \\
(-10.1649)\end{array}$ & $\begin{array}{c}-0.0112 * * * \\
(-14.1078)\end{array}$ & $\begin{array}{c}-0.0006 * * * \\
(-2.9367)\end{array}$ & $\begin{array}{c}-0.0037^{* * *} \\
(-29.2658)\end{array}$ & $\begin{array}{l}-0.0113^{* * *} \\
(-31.6747)\end{array}$ \\
\hline Leverage & $\begin{array}{c}0.0006 * * \\
(2.9419)\end{array}$ & $\begin{array}{c}0.0013 \\
(0.0767)\end{array}$ & $\begin{array}{c}0.0108 \\
(0.0920)\end{array}$ & $\begin{array}{l}-0.0006 \\
(-0.0081)\end{array}$ & $\begin{array}{c}0.0006 * * * \\
(3.5589)\end{array}$ & $\begin{array}{c}0.0056 * * * \\
(17.3765)\end{array}$ \\
\hline ROA & $\begin{array}{c}-0.0842 * * * \\
(-34.9360)\end{array}$ & $\begin{array}{l}-0.0062^{*} \\
(-1.7597)\end{array}$ & $\begin{array}{c}0.1626 \\
(0.2502)\end{array}$ & $\begin{array}{l}-0.0614^{*} \\
(-1.1398)\end{array}$ & $\begin{array}{l}-0.0180^{*} \\
(-1.4993)\end{array}$ & $\begin{array}{c}0.0852 \\
(0.0626)\end{array}$ \\
\hline Risk & $\begin{array}{c}0.0032 * * * \\
(11.5994)\end{array}$ & $\begin{array}{c}0.0032 * * * \\
(9.6271)\end{array}$ & $\begin{array}{c}0.0141 * * * \\
(20.8563)\end{array}$ & $\begin{array}{c}0.0012 * * * \\
(4.5532)\end{array}$ & $\begin{array}{c}0.0020 * * * \\
(7.5822)\end{array}$ & $\begin{array}{c}0.0010 * * * \\
(3.3922)\end{array}$ \\
\hline Constant & $\begin{array}{c}0.0058 \\
(1.1357)\end{array}$ & $\begin{array}{l}0.0911 * * * \\
(14.9880)\end{array}$ & $\begin{array}{l}0.2116 * * * \\
(13.4681)\end{array}$ & $\begin{array}{l}0.0528 * * * \\
(16.5073)\end{array}$ & $\begin{array}{c}0.0885^{* * *} \\
(28.0458)\end{array}$ & $\begin{array}{c}0.2345 * * * \\
(39.6673)\end{array}$ \\
\hline Observations & 613 & 620 & 629 & 817 & 831 & 844 \\
\hline Number of iden & 113 & 114 & 114 & 119 & 120 & 120 \\
\hline $\operatorname{AR}(2)$ & 0.561 & -0.351 & -0.0250 & 0.596 & -0.589 & -0.127 \\
\hline Hansen-test & 105.3 & 101 & 118.54 & 106.6 & 114.9 & 113.7 \\
\hline
\end{tabular}

\section{References}

[1] Jensen M C 1993 The Modern Industrial Revolution, Exit, and the Failure of Internal Control Systems The Journal of Finance 48 831-80

[2] Fraser D R and Zhang H 1995 A note on board directors Appl. Econ. Letters 2 103-6

[3] Saona P, Slocum A, Muro L and Moreno G 2017 Corporate Governance and Strategic Decision Making, ed O L Emeagwali (Rijeka: InTech) pp 177-98

[4] Park Y W and Shin H-H 2004 Board composition and earnings management in Canada Journal of Corporate Finance 10 431-57

[5] Zgarni I, Halioui K and Zehri F 2014 Do the Characteristics of Board of Directors Constrain Real Earnings Management in Emerging Markets? - Evidence from the Tunisian Context IUP Journal of Accounting Research \& Audit Practices 13 46-61

[6] Xie B, Davidson lii W N and DaDalt P J 2003 Earnings management and corporate governance: the role of the board and the audit committee Journal of Corporate Finance 9 295-316

[7] López F, García-Meca E and Tejerina F 2015 Institutional directors and board compensation: Spanish evidence Business Research Quarterly 18 161-73

[8] Brick I E, Palmon O and Wald J K 2006 CEO compensation, director compensation, and firm performance: Evidence of cronyism? Journal of Corporate Finance 12 403-23

[9] Chen Y-C, Lee C-H and Chou P-I 2015 Stock-Based Compensation and Earnings Management Behaviors Review of Pacific Basin Financial Markets and Policies 181550008 (33 pages) 
[10] Sun B 2014 Executive compensation and earnings management under moral hazard J. Econ. Dynam. Control 41 276-90

[11] Ye K 2014 Independent director cash compensation and earnings management Journal of Accounting and Public Policy 33 391-400

[12] Adams R B and Ferreira D 2008 Do directors perform for pay? J. Acc. Econ. 46 154-71

[13] Kim J Y, Roden D M and Cox S R 2013 The Composition and Compensation of the Board of Directors as Predictors of Corporate Fraud Accounting and Finance Research 2 142-54

[14] Vafeas N 2000 Operating performance around the adoption of director incentive plans Econ. Letters 68 185-90

[15] Arellano M and Bond S 1991 Some tests of specification for panel data: Monte Carlo evidence and an application to employment equation The Review of Economic Studies 58 277-97

[16] Brown P, Beekes W and Verhoeven P 2011 Corporate governance, accounting and finance: A review Accounting \& Finance 51 96-172

[17] Alonso-Borrego C and Arellano M 1999 Symmetrically normalized instrumental variable estimation using panel data Journal of Business \& Economic Statistics 17 36-49

[18] Arellano M and Bover O 1995 Another look at the instrumental variable estimation of errorcomponents models J. Econometrics 68 29-51

[19] Blundell R and Bond S 1998 Initial conditions and moment restrictions in dynamic panel data models J. Econometrics 87 115-43

[20] Dechow P M, Sloan R G and Sweeney A P 1995 Detecting Earnings Management Acc. Rev. 70 193225

[21] García B and Gill-de-Albornoz B 2007 The effect of the board composition and its monitoring committees on earnings management: Evidence from Spain Corporate Governance: An International Review 15 1413-28

[22] Jones J J 1991 Earnings Management During Import Relief Investigations J. Acc. Res. 29 193-228

[23] Kasznik R 1999 On the Association between Voluntary Disclosure and Earnings Management $J$. Acc. Res. 37 57-81

[24] Altman E I 1968 Financial ratios, discriminant analysis and the prediction of corporate bankruptcy The Journal of Finance 23 589-609

[25] Lind J T and Mehlum H 2010 With or Without U? The Appropriate Test for a U-Shaped Relationship Oxford Bull. Econ. Statist. 72 109-18

[26] Vafeas N 1999 Board meeting frequency and firm performance J. Finan. Econ. 53 113-42

[27] Saona P and Vallelado E 2010 Is the use of bank debt as a governance mechanism conditioned by the financial system? The cases of Chile and Spain Appl. Econ. 42 1709-26 